\title{
Upaya Guru Mengembangkan Media Visual dalam Proses Pembelajaran Fiqih di MAN Kuok Bangkinang Kabupaten Kampar
}

\author{
ZULKIFLI RUSBY * \\ NAJMI HAYATI ** \\ INDRA CAHYADI ${ }^{* * *}$
}

\begin{abstract}
* Fakultas Agama Islam (FAI) Universitas Islam Riau (UIR) Jl. Kaharuddin Nasution, No.113, Perhentian Marpoyan Pekanbaru 28284, Email: zulkiflirusby@yahoo.com

** Fakultas Agama Islam ( FAI ) Universitas Islam Riau ( UIR ) Jl. Kaharuddin Nasution No. 113, Pekanbaru. Telepon (0761) 45005, Email : najmi perdana@yahoo.co.id

***Fakultas Agama Islam (FAI) Universitas Islam Riau (UIR) Pekanbaru

Jl. Kaharuddin Nasution, No. 113, Perhentian Marpoyan Pekanbaru 28284
\end{abstract}

\begin{abstract}
Abstrak: Upaya adalah salah satu usaha atau syarat untuk mencapai sesuatu maksud tertentu. Media visual merupakan media pembelajaran yang menyalurkan pesan lewat penglihatan. Yang terjadi dalam mengembangkan media visual di MAN Kuok Bangkinang, masih belum berjalan dengan maksimal hal tersebut terlihat dari gejala seperti guru kurang kreatif dalam mengembangkan media visual, guru kurang kreatif dalam menganalisis kebutuhan dan karakteristik siswa. Pembatasan masalah dalam penelitian ini adalah: Upaya guru mengembangkan media visual, khususnya media foto/gambar dalam proses pembelajaran Bidang studi Fiqih di MAN Kuok Bangkinang Kabupaten Kampar. Sejalan dengan masalah, maka dapat dirumuskan sebagai berikut: Apa saja upaya guru mengembangkan media visual dalam proses pembelajaran bidang studi Fiqih? Penelitian ini bertujuan untuk mengetahui upaya guru mengembangkan media visual dalam proses pembelajaran bidang studi Fiqih. Jenis penelitian ini adalah Deskriptif Kualitatif. Populasi penelitian ini adalah guru bidang studi Fiqih MAN Kuok yakni 2 orang guru, dan dalam pengumpulan data penulis menggunakan tehnik wawancara, kemudian datanya dianalisis untuk memperoleh hasil. Berdasarkan hasil penelitian dan analisis data dengan menggunakan metode deskriptif kualitatif, maka dapat disimpulkan bahwa upaya guru mengembangkan media visual adalah Menganalisis kebutuhan dan karakteristik siswa, Merumuskan tujuan instruksional, Merumuskan butir-butir materi, Mengembangkan alat pengukur keberhasilan, Menulis naskah media, Mengadakan tes dan revisi.
\end{abstract}

Kata kunci: upaya, media visual, pembelajaran fiqih

\section{PENDAHULUAN}

Belajar adalah suatu proses yang kompleks yang terjadi pada diri setiap orang sepanjang hidupnya. Salah satu pertanda bahwa seseorang itu telah belajar adalah adanya perubahan tingkah laku pada diri orang itu yang mungkin di sebabkan oleh terjadinya perubahan pada tingkat pengetahuan, keterampilan, atau sikapnya. Interaksi yang terjadi selama proses belajar tersebut dipengaruhi oleh lingkungannya, antara lain murid, guru, petugas perpustakaan, kepala sekolah, 
bahan atau materi pelajaran (buku, modul, majalah, dan lain-lain), dan berbagai sumber belajar dan fasilitas (video, radio, televise, computer, dan lain-lain).

Perkembangan ilmu pengetahuan dan teknologi semakin mendorong upaya-upaya pembaharuan dalam pemanfaatan hasil-hasil terknologi dalam proses belajar. Para guru dituntut agar mampu menggunakan alat-alat yang dapat disediakan oleh sekolah, dan tidak menutup kemungkinan bahwa alat-alat tersebut sesuai dengan perkembangan dan tuntutan zaman, dalam upaya mencapai tujuan pengajaran yang diharapkan. Disamping itu, guru juga dituntut untuk mengembangkan keterampilan membuat media pembelajaran yang akan digunakannya apakah media tersebut belum tersedia.

Salah satunya media berbasis visual dalam mendesain media pembelajaran. Dimana media visual menjadi media yang mempunyai unsur penting dalam pengembangan mata pelajaran Fiqih. Media visual yaitu media semua alat-alat peraga yang memfungsikan organ indra penglihatan siswa, misalnya: foto, lukisan, alat peraga, kaligrafi dan lain-lain.

Media adalah manusia, materi, atau kejadian yang membangun kondisi yang membuat siswa mampu memperoleh pengetahuan, keterampilan, atau sikap. Secara lebih khusus, pengertian media dalam proses belajar mengajar cenderung diartikan sebagai alat-alat grafis, photo grafis, atau elektronis untuk menangkap, memproses, dan menyusun kembali informasi visual.

Media pembelajaran meliputi alat yang secara fisik digunakan untuk menyampaikan isi materi pelajaran, misal buku, kaset, video, camera, film, foto, gambar dan lain-lain (Azhar Arsyad, 2011:3-4).
Kata media pendidikan digunakan secara bergantian dengan istilah alat Bantu atau media komunikasi seperti yang di kemukakan oleh Hamalik (1986) dimana ia melihat bahwa hubungan komunikasi akan berjalan lancar dengan hasil yang maksimal apabila menggunakan alat Bantu yang disebut media komunikasi.

Media berbasis visual (image dan perumpamaan) memegang peranan yang sangat penting dalam proses belajar. Media visual dapat memperlancar pemahaman, memperkuat ingatan, menumbuhkan minat siswa dan dapat memberikan hubungan antara isi materi pelajaran dengan dunia nyata. Agar menjadi efektif, visual sebaliknya di tempatkan pada konteks yang bermakna dan siswa harus berinteraksi dengan visual (image) itu untuk meyakinkan terjadinya proses informasi (Azhar Arsyad, 2011:91).

Bentuk visual bisa berupa: (a) Gambar representasi seperti, gambar, lukisan atau foto yang menunjukkan bagaimana tampaknya sesuatu benda; (b) Diagram yang melukiskan hubungan-hubungan konsep, organisasi, dan struktur isi materi; (c) Peta yang menunjukkan hubunganhubungan ruang antara unsur-unsur dalam isi materi; dan (d) Grafik seperti tabel, grafik, chart (bagan) yang menyajikan gambaran atau kecenderungan data atau antar hubungan seperangkat gambar atau angka-angka (Azhar Arsyad, 2011:9192).

$\begin{array}{lll}\text { Dalam kegiatan belajar mengajar } & \\ \text { seorang guru harus pandai }\end{array}$ menggunakan media didalam proses pembelajarannya, agar siswa tidak merasa jenuh dan merasakan pembelajaran yang menarik.

Dalam upaya mengembangkan media visual didalam proses pembelajaran, guru harus bisa 
membuat suatu media untuk membantu dalam belajar agar menumbuhkan minat belajar siswa. Semangat guru mengembangkan media visual dalam mengajar terhadap materi yang di ajarkan berhubungan erat dengan minat dan motivasi siswa dalam belajar. Karena guru yang mepunyai semangat mengajar yang tinggi dalam mengajar terhadap materi yang di ajarkan, dan hal tersebut tidak lepas dari penggunaan media visual, ini akan mempengaruhi motivasi dan minat siswa terhadap materi yang di ajarkan.

Berdasarkan studi pendahuluan melalui pengamatan di lapangan, penulis menemukan gejala-gejala sebagai berikut: (1) Guru kurang kreatif dalam mengembangkan media visual; (2) Guru jarang menggunakan media visual didalam proses pembelajaran; (3) Guru kurang kreatif dalam menganalisis kebutuhan dan karakteristik siswa; dan (4) Sebagian guru tidak mampu memilih dan menggunakan media visual dalam pembelajaran sesuai dengan konteks materi yang diajarkan.

Berdasarkan latar belakang dan Gejala-gejala di atas, penulis terdorong untuk melakukan penelitian dengan judul: "Upaya Guru Mengembangkan Media Visual dalam Proses Pembelajaran Bidang Studi Fiqih di MAN Kuok Bangkinang Kabupaten Kampar"

Mengingat luasnya permasalahan serta keterbatasan waktu dan tenaga yang dimiliki, serta untuk fokus dan tercapainya objek penelitian, maka penulis perlu membatasi permasalahannya, yaitu tentang Upaya Guru Mengembangkan Media Visual, Khususnya Media Foto/Gambar dalam Proses Pembelajaran Bidang Studi Fiqih di MAN Kuok Bangkinang Kabupaten Kampar.

Berdasarkan pada latar belakang permasalahan dan pembatasan masalah tersebut di atas, penulis merumuskan masalah penelitian ini sebagai berikut: Apa Saja Upaya Guru Mengembangkan Media Visual dalam Proses Pembelajaran Bidang Studi Fiqih di MAN Kuok Bangkinang Kabupaten Kampar? Penelitian ini bertujuan untuk mengetahui Upaya Guru Mengembangkan Media Visual dalam Proses Pembelajaran Bidang Studi Fiqih di MAN Kuok Bangkinang Kabupaten Kampar.

\section{KONSEP TEORI Hakikat Upaya Guru}

Menurut Kamus Bahasa Indonesia pengertian upaya adalah usaha, ikhtiar untuk mencapai suatu yang dimaksud, memecahkan persoalan, mencari jalan keluar (Kamus Besar Bahasa Indonesia, 2012:1534).

Menurut bahasa, dalam Kamus Besar Bahasa Indonesia pengertian usaha adalah seperti berikut ini: (1) Usaha adalah kegiatan dengan mengarahkan tenaga, pikiran, atau badan untuk mencapai suatu maksud; dan (2) Usaha adalah pekerjaan (perbuatan, prakarsa, ikhtiar, daya upaya) untuk mencapai sesuatu (Departemen Pendidikan Nasional, 2005:1254).

Upaya adalah salah satu usaha atau syarat untuk mencapaikan sesuatu maksud tertentu, usaha, akal, ikhtiar boleh juga dikatakan suatu kegiatan dengan mengarah tenaga, pikiran atau badan untuk mencapai sesuatu yang dimaksud tujuan (Dessy Anwar, 2001:578).

Upaya guru adalah suatu aktifitas guru yang dilakukan dalam rangka membimbing, mendidik, mengajar, dan melakukan transfer knowledge kepada anak didik sesuai dengan kemampuan dan keprofesional yang dimiliki, sehingga mencapai suatu yang diinginkan atau hendak dicapai (Abdul Rachman Saleh, 2006:277). 
Guru mempunyai tugas untuk mendorong, membimbing, dan memberi fasilitas belajar bagi siswa untuk mencapai tujuan. Guru mempunyai tanggung jawab untuk melihat segala sesuatu yang terjadi dalam kelas untuk membantu proses perkembangan siswa (Slameto, 2010:97).

Pendidik adalah orang dewasa yang bertanggung jawab memberi bimbingan atau bantuan kepada anak didik dalam perkembangan jasmani dan rohaninya agar mencapai kedewasaannya, mampu melaksanakan tugasnya sebagai makhluk Allah swt, khalifah di permukaan bumi, sebagai makhluk sosial sebagai individu yang sanggup berdiri sendiri (Nur Uhbiyati, 2005:65).

Guru seharusnya memiliki persyaratan sebagai berikut: (a) Bertakwa kepada Tuhan Yang Maha Esa; (b) Mempunyai kesadaran akan tugasnya disertai tanggung jawab; (c) Rasa wajib melaksanakan tugasnya disertai rasa tanggung jawab; (d) Memiliki rasa tanggung jawab terhadap peserta didik; (e) Senantiasa meningkatkan pengetahuan, nilai-nilai, dan keterampilan yang dimilikinya; (f) Membina hubungan baik dengan masyarakat dan menikuti perkembangan masyarakat; dan (g) Membina nilai-nilai yang dijunjung tinggi oleh masyarakat, bangsa, dan negara (Novan Ardy Wiyani, 2012:110).

\section{Hakikat Media Visual dalam Pembelajaran}

Menurut Kamus Besar Indonesia Media adalah alat (sarana) komunikasi seperti koran, majalah, radio, televisi, film, poster, dan spanduk atau perantara atau penghubung (Kamus Besar Bahasa Indonesia, 2012 : 892).

Kata media berasal dari bahasa latin yang merupakan bentuk jamak dari kata medium yang secara harfiah berarti "perantara" atau pengantar. AECT (Assosiation of Education and Communication Technology) memberikan batasan tentang media sebagai segala bentuk dan saluran yang digunakan untuk menyampaikan pesan atau informasi. Media pembelajaran adalah segala sesuatu yang dapat digunakan untuk menyalurkan pesan dari pengirim ke penerima sehingga merangsang pikiran, perasaan, perhatian dan minat serta kemauan peserta didik sedemikian rupa sehingga proses belajar terjadi dalam rangka mencapai tujuan pembelajaran secara efektif (Arief S. Sadiman, 2006:6).

Agar proses belajar dapat efektif perlu juga disesuaikan dengan tipe atau gaya belajar peserta didik. Secara umum dikenal tiga macam gaya belajar, yaitu visual, auditorial dan kinestetik. Belajar visual adalah belajar melalui apa yang mereka lihat, pelajar auditorial melakukannya melalui apa yang mereka dengar, sedangkan kinestetik belajar lewat gerak dan sentuhan (Bobbi De Porter dan Mike Hernacki, 2003:112).

Ciri gaya belajar visual adalah: (1) Teliti terhadap yang detail; (2) Mengingat dengan mudah apa yang dilihat; (3) Mempunyai masalah dengan instruksi lisan; (4) Tidak mudah terganggu dengan suara; (5) Pembaca cepat dan tekun; (6) Lebih suka membaca dari pada dibacakan; (7) Lebih suka metode demonstrasi dari pada ceramah; (8) Bila menyampaikan gagasan sulit memilih kata; (9) Rapi dan teratur; dan (10) Penampilan sangat penting.

Menurut Kamus Besar Indonesia Visual adalah dapat dilihat dengan indra penglihatan (mata), berdasarkan penglihatan (Kamus Besar Bahasa Indonesia, 2012:1549).

Ciri-ciri media pendidikan tersebut adalah: (1) Ciri fiksatif (Fixative Property). Ciri ini meng- 
gambarkan kemampuan media merekam, menyimpan, melestarikan, dan merekonstruksi suatu peristiwa atau objek; (2) Ciri manipulatif (Manipulative Property). Transpormasi suatu kejadian atau objek dimungkinkan karna media memiliki ciri manipulatif. Kejadian yang memakan waktu berhari-hari dapat disajikan kepada siswa dalam waktu dua atau tiga menit; dan (3) Ciri distributif (Distributive Property). Ciri distributif dari media memungkinkan suatu objek atau kejadian ditransfortasikan melalui ruang, dan secara bersamaan kejadian tersebut disajikan kepada sejumlah besar peserta didik dengan stimulus pengalaman yang relatif sama mengenai kejadian itu (Azhar Arsyad, 2011:1214).

Media pembelajaran dapat memenuhi tiga fungsi utama apabila media itu digunakan untuk perorangan, kelompok, atau kelompok pendengar yang besar jumlahnya, yaitu : memotivasi minat atau tindakan, menyajikan informasi, dan memberi instruksi (Azhar Arsyad, 2011:16).

Berbagai kegunaan atau manfaat media pembelajaran telah dibahas oleh banyak ahli. Maka dapat disimpulkan beberapa kegunaan praktis dari penggunaan media pembelajaran di dalam proses belajar mengajar adalah sebagai berikut: (1) Media pembelajaran dapat memperjelas penyajian pesan dan informasi sehingga dapat memperlancar dan meningkatkan proses dan hasil belajar; (2) Media pembelajaran dapat meningkatkan dan mengarahkan perhatian anak sehingga dapat menimbulkan motivasi belajar, interaksi yang lebih langsung antara peserta didik dan lingkungannya, dan kemungkinan peserta didik untuk belajar sendiri-sendiri sesuai dengan kemampuan dan minatnya; dan (3)
Media pembelajaran dapat mengatasi keterbatasan indra, ruang dan waktu.

Media pembelajaran merupakan komponen pembelajaran yang meliputi bahan dan peralatan. Dengan masuknya berbagai pengaruh ke dalam dunia pendidikan (misalnya teori/konsep baru dan teknologi), media pembelajaran terus mengalami perkembangan dan tampil dalam berbagai jenis dan format, dengan masing-masing ciri dan kemampuannya sendiri.

Pemilihan suatu media tertentu oleh seorang guru didasarkan atas pertimbangan antara lain: (a) ia merasa sudah akrab dengan media itu misalnya papan tulis atau proyektor transparansi, (b) ia merasa bahwa media yang dipilihnya sendiri dapat menggambarkan dengan lebih baik dari pada dirinya sendiri, misalnya diagram pada flip chart, atau (c) media yang dipilihnya dapat menarik minat dan perhatian peserta didik, serta menuntunnya pada penyajian yang lebih terstruktur dan terorganisasi.

\section{Pengembangan Media Pembelajaran Berbasis Visual}

Dalam Kamus Bahasa Indonesia pengembangan adalah proses, cara, perbuatan pengembangan. Istilah pengembangan menunjukkan kepada suatu kegiatan yang menghasilkan suatu cara yang baru, dimana selama kegiatan tersebut, penilaian dan penyempurnaan terhadap cara tersebut terus dilakukan (Heri Gunawan, 2012:43).

Menurut Arief S. Sadiman dkk, media pembelajaran berbasis visual adalah media pembelajaran yang menyalurkan pesan lewat indra pandang/penglihatan. Secara umum media pembelajaran berbasis visual dikelompokkan menjadi dua macam, yaitu media grafis dan media OHT/ OHP. 


\section{Media Grafis}

Media grafis dapat diartikan sebagai media visual yang berfungsi untuk menyalurkan pesan dari sumber ke penerima pesan melalui perpaduan antara pengungkapan kata-kata dan gambar. Banyak jenis media grafis, beberapa diantaranya akan dibicarakan dalam bahasan di bawah ini: Pertama, Media gambar/foto. Gambar/foto merupakan salah satu media pembelajaran yang amat dikenal di dalam setiap kegiatan pembelajaran. Adapun beberapa keunggulan dari media gambar/foto itu antara lain: (a) Media gambar/foto dapat mengatasi keterbatasan pengamatan visual kita. Sel daun yang tak mungkin kita lihat dengan mata telanjang dapat disajikan dengan jelas dalam bentuk gambar atau foto; (b) Foto dapat memperjelas suatu masalah, dalam bidang apa saja dan tingkat usia berapa saja, sehingga dapat mencegah atau membetulkan kesalah pahaman; dan (c) Foto berharga murah dan gampang didapat serta digunakan, tanpa memerlukan peralatan khusus.

Sementara itu, beberapa kelemahan media gambar/ foto setidaktidaknya ada tiga macam, yaitu: (1) gambar/foto hanya menekankan persepsi indra mata, (2) gambar/foto benda terlalu kompleks kurang efektif untuk kegiatan pembelajaran, (3) ukurannya sangat terbatas untuk kelompok besar.

Selain itu, ada enam syarat yang perlu dipenuhi oleh gambar/ foto yang baik sehingga dapat dijadikan sebagai media pendidikan, yaitu: (a) autentik. Gambar tersebut harus secara jujur melukiskan situasi seperti kalau orang melihat benda sebenarnya; (b) sederhana. Maksudnya komposisi gambar hendaknya cukup jelas menunjukkan poin-poin pokok dalam gambar; (c) ukuran relatif. Gambar atau foto dapat memperbesar atau memperkecil objek/ benda sebenarnya; (d) gambar/foto sebaiknya mengandung gerak atau perbuatan; (e) gambar yang bagus belum tentu baik untuk mencapai tujuan pembelajaran; (f) tidak setiap gambar yang bagus merupakan media yang bagus (Arief S. Sadiman, 2006:29-32).

Kedua, media sketsa. Sketsa adalah gambar yang sederhana, atau draf kasar yang melukiskan bagianbagian pokoknya tanpa detail. Seni sketsa sudah banyak dibicarakan orang lewat koran-koran atau pameran tertantu, sehingga bukan merupakan barang baru. Sketsa sudah merupakan tradisi sejak seni lukis ada.

Ketiga, media bagan/ chart. Bagan/ chart adalah media visual yang berfungsi pokok menyajikan ide-ide atau konsep-konsep yang sulit bila hanya disampaikan secara tertulis atau lisan secara visual. Sebagai media yang baik, bagan haruslah: (a) dapat dimengerti anak; (b) sederhana dan lugas, tidak rumit atau berbelit-belit; dan (c) diganti pada waktu-waktu tertentu agar selain tetap termasa juga tak kehilangan daya tarik (Arief S. Sadiman, 2006:35).

Keempat, media grafik. Grafik adalah media visual dalam bentuk gambar sederhana untuk menyajikan data kuantitatif (data berangka) yang menggunakan titik-titik, garis atau gambar. Grafik adalah alat penyajian data statistik yang tertuang dalam bentuk lukisan, baik lukisan garis, gambar maupun lambang (Anas Sudijono, 2003:57).

Fungsi grafik adalah menggambarkan data kuantitatif secara teliti, menerangkan perkembangan atau perbandingan sesuatu objek atau peristiwa yang saling berhubungan secara singkat dan jelas.

Sebagai media pendidikan, grafik dapat dikatakan baik kalau memenuhi ketentuan sebagai berikut: (a) jelas untuk dilihat oleh seluruh kelas; (b) 
hanya menyajikan satu ide setiap grafik; (c) ada jarak/ruang kosong antara kolom-kolom bagiannya; (d) warna yang digunakan kontras dan harmonis; (e) berjudul dan ringkas; (f) sedarhana; (g) mudah dibaca; (h) praktis, mudah diatur; (i) menggambarkan kenyataan; (j) menarik; (k) jelas dan tak memerlukan informasi tambahan; dan (l) teliti (Arief S. Sadiman, 2006:40)

Kelima, media papan tulis, papan flanel dan buletin. Papan tulis adalah papan dari kayu dengan permukaan yang bisa ditulis ulang dengan menggunakan kapur tulis. Keuntungan dari papan tulis adalah sebagai berikut: (1) dapat digunakan di segala jenis dan tingkat lembaga pendidikan; (2) mudah untuk mengawasi keaktifan kelas; (3) lebih ekonomis, karena mudah untuk ditulis dan dihapus kembali dan dapat dipakai berkali-kali; (4) bila perlu guru dapat mempersiapkan terlebih dahulu tulisan di papan tulis, kemudian membalikkannya atau menutup dengan tirai hitam.

$$
\text { Adapun sisi kelemahan }
$$

penggunaan papan tulis, yaitu: (a) apabila guru terlalu lama menulis di papan tulis, maka aktivitas peserta didik sukar diawasi; (b) debu kapur tulis dapat terhirup guru dan mengganggu kesehatan; dan (c) bagi guru yang tulisannya kurang bagus, maka akibatnya dapat kurang menguntungkan bagi guru sendiri maupun peserta didik.

Papan flanel adalah papan yang berlapis kain flanel sehingga gambar yang akan disajikan dapat dipasang, dilipat dan dilepas dengan mudah dan dapat dipakai berkali-kali. Papan flanel termasuk salah satu media pembelajaran dua dimensi, yang dibuat dari kain flanel yang ditempelkan pada sebuah tripleks, papan atau gabus. Kemudian membuat guntinganguntingan flanel yang diletakkan di bagian belakang gambar.
Media papan flanel adalah media grafis yang efektif sekali untuk menyajikan pesan-pesan tertentu kepada sasaran tertentu pula. Papan flanel ini dapat menggunakan kain atau kertas plano secara berlapis. Papan flanel tersedia dalam berbagai variasi warna, murah dan mudah didapat.

Kelebihan menggunakan papan flanel adalah: (1) gambar-gambar dengan mudah ditempelkan; efisiensi waktu dan tenaga; (3) menarik perhatian peserta didik; memudahkan guru menjelaskan materi pelajaran.

Adapun kelemahan menggunakan papan flanel yaitu antara lain: (a) memerlukan waktu lama untuk mempersiapkan materi; (b) memerlukan biaya yang mahal untuk mempersiapkannya; (c) sukar menampilkan pada jarak yang jauh; dan (d) flanel mempunyai daya rekat yang kurang kuat.

Papan buletin adalah papan yang khusus digunakan untuk mempertunjukkan contoh-contoh pekerjaan siswa, gambar, bagan, poster dan objek dalam bentuk tiga dimensi. Papan buletin sering kali ditempatkan di aula, cafetaria, dan kantor, tapi tempat utamanya adalah di dalam kelas (Arief S. Sadiman dkk, 2005:49).

Kelebihan menggunakan papan buletin, yaitu: (1) meningkatkan minat belajar dan berkarya pada diri siswa; (2) menyatukan semangat kelas; (3) mendorong siswa untuk berkarya dan menciptakan produk, berinisiatif memecahkan masalah; dan (4) sarana berkompetensi.

Adapun kelemahan menggunakan papan buletin, yaitu antara lain: (a) memerlukan waktu yang lama untuk mempersiapkan materi, memerlukan biaya yang mahal untuk mempersiapkannya, dan (c) sukar menampilkan pada jarak yangjauh. 
Keenam, pengembangan media poster. Pada prinsipnya, poster merupakan gagasan yang dicetuskan dalam bentuk ilustrasi gambar yang disederhanakan yang dibuat dalam bentuk ukuran besar, bertujuan untuk menarik perhatian, membujuk, memotivasi, atau memperingatkan pada gagasan pokok, fakta atau peristiwa tertentu. Poster memiliki kekuatan yang dramatik yang begitu tinggi memikat dan menarik perhatian. Banyak iklan menggunakan teknik-teknik poster dalam menarik perhatian demi kepentingan produksinya. Poster dapat menarik perhatian karena uraian yang memadai secara kejiwaan dan merangsan untuk dihayati.

Sebagai salah satu media pembelajaran, poster memiliki kelebihan, diantaranya adalah: (a) Dapat membantu guru dalam menyampaikan pelajaran dan membantu peserta didik belajar; (b) Menarik perhatian, dengan demikian mendorong peserta didik untuk lebih giat belajar; (c) Dapat ditempelkan dimana-mana, sehingga memberi kesempatan kepada peserta didik untuk mempelajari dan mengingat kembali apa yang telah dipelajari; dan (d) Dapat menyarankan perubahan tingkah laku kepada peserta didik yang melihatnya.

Adapun beberapa kelemahan poster adalah: (1) sangat dipengaruhi oleh tingkat pengetahuan orang yang melihatnya; (2) karena tidak adanya penjelasan yang terinci, maka dapat menimbulkan interprestasi yang bermacam-macam dan mungkin merugikan; (3) suatu poster akan banyak mengandung arti bagi kalangan tertentu, tetapi dapat juga tidak menarik bagi kalangan yang lainnya; dan (4) bila poster terpasang lama di suatu tempat maka akan berkurang nilainya, bahkan akan membosankan orang yang melihatnya.
Ketujuh, media kartun. Kartun adalah suatu gambar interpretatif yang menggunakan simbol-simbol untuk menyampaikan sesuatu pesan secara tepat dan ringkas untuk sesuatu sikap terhadap orang, situasi, atau kejadiankejadian tertentu (Arief S. Sadiman, 2006:45).

Sebagaimana media poster, kartun sebagai salah satu media pembelajaran juga mempunyai kelebihan dan kekurangan. Kelebihannya adalah: (a) Penggunaan simbolisme yang singkat dan langsung mengena pada sasaran; (b) Mengemukakan suatu ide atau pesan, peristiwa secara estetis, menggembirakan, lucu, menyindir dan mengejek; (c) Mengemukakan ide atau pesan, peristiwa secara stereotipe mudah dikenal umum; dan (d) Tidak memerlukan banyak penjelasan atau kata-kata.

Adapun kelemahannya yaitu: (a) proses stereotipe ini justru dapat menyebabkan terjadinya salah mewakili dan salah pengertian, (b) sering menyederhanakan ide atau peristiwa, sehingga dapat salah mewakili sesuatu, dan (c) apabila guru salah memanfaatkannya dan salah memberikan penjelasan, maka akan membingungkan peserta didik saja.

Kedelapan, media peta dan globe. Pada saat ini, yang berada pada abad kemajuan teknologi, sehingga seakanakan terasa dunia ini bertambah kecil, berbagai kejadian di dunia dalam tempo yang amat cepat dapat di sajikan.

Peta adalah gambaran permukaan bumi pada bidang datar dengan skala tertentu melalui suatu sistem proyeksi. Peta bisa disajikan dalam berbagai cara yang berbeda, mulai dari peta konvensional yang tercetak hingga peta digital yang tampil di layar komputer.

Kelebihan peta dan globe bila digunakan sebagai media dalam proses pembelajaran adalah:

Memungkinkan peserta didik untuk 
mengerti posisi dan kesatuan politik, daerah kepulauan; (b) Merangsang minat peserta didik untuk mengetahui penduduk dan pengaruh-pengaruh geografis dan iklim; (c) Mungkin juga peserta didik memperoleh gambaran tentang distribusi penduduk, tumbuhtumbuhan, kehidupan hewan, serta bentuk bumi yang sebenarnya; dan (d)

Dengan memperhatikan hal-hal tersebut, peta dan globe sangat penting untuk mengkonkretkan pesan-pesan yang abstrak.

Adapun kekurangan penggunaan media peta dan globe antara lain: (1) Terkadang tidak semua sekolah menyediakan peta yang besar. Peta yang digunakan peta-peta yang kecil, sehingga tidak efektif bila jumlah kelas cukup besar; (2) Globe yang dimiliki sekolah-sekolah biasanya kecil, sehingga tidak bisa menjangkau semua peserta didik seluruh kelas; (3) Gambar di peta ataupun di globe kecil sehingga tidak bisa terlihat oleh semua siswa yang ada di kelas tersebut; dan (4) Peta yang secara khusus berkaitan dengan pembelajaran pendidikan agama Islam masih cukup sedikit, sehingga guru harus kreatif untuk membuat sendiri.

\section{Media OHT/OHP}

Media transparansi atau overhead transparency (OHT) sering kali disebut dengan nama perangkat kerasnya yaitu OHP (overhead projector). Media transparansi adalah media visual proyeksi, yang dibuat di atas bahan transparan, biasanya film acetate atau plastik berukuran $81 / 2$ " $\mathrm{x}$ 11", yang digunakan oleh guru untuk memvisualisasikan konsep, proses, fakta, statistik, kerangka outline, atau ringkasan di depan kelompok kecil/ besar (Arief S. Sadiman, 2006:61).

Kelebihan media transparansi antara lain: (1) Gambar yang diproyeksikan lebih jelas dibanding gambar di papan, ruangan tak perlu di gelapkan, sehingga siswa dapat melihatnya sambil mencatat; (2) Guru sambil mengajar dapat berhadapan dengan siswa; (3) Benda-benda kecil dapat diproyeksikan hanya dengan meletakkannya di atas $\mathrm{OHP}$, walaupun hasilnya berupa bayang-bayang; (4) Memungkinkan penyajian diskriminasi warna dan menarik minat siswa; (5) Tidak memerlukan tenaga bantuan operator dalam menggunakan OHP karena mudah dioperasikan; (6) Lebih sehat dari pada papan tulis; (7) Praktis dapat dipergunakan untuk semua ukuran kelas ruangan; (8) Mempunyai variasi teknik penyajian yang menarik dan tidak membosankan, terutama untuk proses yang kompleks dan bertahap; (9) Menghemat tenaga dan waktu karena dapat dipakai berulangulang; (10) Sepenuhnya di bawah kontrol guru; (11) Dapat dipakai sebagai petunjuk sistematika penyajian guru, dan apabila menggunakan bingkai, catatan-catatan tambahan untuk mengingatkan si guru dibuat di atasnya; dan (12) Dapat menstimulus efek gerak yang sederhana dan warna pada proyeksinya dengan menambahkan alat penyajian tertentu (Arief S. Sadiman, 2006:63).

Sekalipun banyak kelebihan media transparansi memiliki banyak keterbatasan, yaitu: (a) Pemakaiannya terbatas hanya sebagai alat bantu pembelajaran baik bagi guru maupun peserta didik jarang dapat digunakan sebagai medium instruksional; (b) Pendistribusiannya rumit (baik pendistribusian lembar demi lembar maupun pendistribusian dalam set), tidak seperti film bingkai atau film rangkai yang lebih ringkas. Transparansi multiwarna, baik yang diproduksi secara lokal maupun komersial, mungkin malah lebih mahal dari produksi film bingkai; (c) Kalau sedang menggunakan OHP, sewaktu 
mengganti transparansi, ada kekosongan yang menyilaukan di layar; dan (d) Karena didesain untuk dipergunakan dalam proyeksi di depan layar, jarang digunakan untuk proyeksi dari belang, kecuali dalam keadaan luar biasa.

Adapun penelitian yang relevan dalam masalah ini adalah penelitian yang dilakukan oleh Endang Utari (Fakultas Agama Islam Universitas Islam Riau, 2015). Yang berjudul: Upaya Guru dalam Memanfaatkan Sumber Pembelajaran Bidang Studi Pendidikan Agama Islam di Sekolah Menengah Atas Negeri 5 Dumai, hasil dari penelitian adalah guru telah memanfaatkan sumber pembelajaran bidang studi pendidikan agama islam di SMA N 5 Dumai.

Meskipun penelitian yang dilakukan oleh Endang Utari hampir memiliki kesamaan, yakni sama-sama membahas tentang Upaya Guru dalam Memanfaatkan Sumber Pembelajaran Bidang Studi Pendidikan Agama Islam di Sekolah Menengah Atas Negeri 5 Dumai. Tetapi pada penelitian saya, saya memfokuskan kepada upaya guru Fiqih mengembangkan media visual dalam proses pembelajaran di MAN Kuok Bangkinang Kabupaten Kampar. Jadi penelitian saya dan penelitian Endang Utari memiliki perbedaan baik dari judul penelitian, tempat penelitian, waktu penelitian, dan objek penelitian. Penelitian serupa juga di lakukan oleh Eni Rozita (Fakultas Agama Islam Universitas Islam Riau, 2012). Yang berjudul: Usaha Guru Menggunakan Media dalam Proses Belajar Mengajar di PDTA Al-Huda Kecamatan Kundur Kabupaten Karimun, hasil dari penelitian adalah dengan jumlah yang dilaksanakan 123 kali dan tidak terlaksana 117 kali dari seluruh indikator, sehingga keseluruhan indikator 240 kali, dan hasil pelaksanaanya tergolong "Kurang
Baik" sesuai yang tertera pada hasil observasi yaitu dengan persentase $51,25 \%$.

Meskipun penelitian yang dilakukan oleh Eni Rozita hampir memiliki kesamaan, yakni sama-sama membahas tentang Usaha Guru Menggunakan Media dalam Proses Belajar Mengajar di PDTA Al-Huda Kecamatan Kundur Kabupaten Karimun. Tetapi pada penelitian saya, saya memfokuskan kepada upaya guru Fiqih mengembangkan media visual dalam proses pembelajaran di MAN Kuok Bangkinang Kabupaten Kampar. Jadi penelitian saya dan penelitian Eni Rozita memiliki perbedaan baik dari judul penelitian, tempat penelitian, waktu penelitian, dan objek penelitian. Selanjutnya, penelitian ini di lakukan oleh Lissuryani (Fakultas Agama Islam Universitas Islam Riau, 2012). Yang berjudul: Kemampuan Guru Pendidikan Agama Islam dalam penyusunan dan Pengembangan Bahan Ajar di SDN 001 Pantai Raja Kecamatan Perhentian Raja Kabupaten Kampar, hasil dari penelitian adalah dapat digolongkan dalam kategori "Kurang", hal ini dikarenakan masih banyaknya kendalakendala dalam pengembangan bahan ajar, dan kurang dalamnya dalam menganalisis kurikulum sehingga tidak maksimalnya hasil dari proses belajar mengajar, serta hanya menggunakan satu sumber buku penunjang serta kurangnya dalam penguasaan kelas.

Meskipun penelitian yang dilakukan oleh Lissuryani hampir memiliki kesamaan, yakni sama-sama membahas tentang Penyusunan dan Pengembangan Bahan Ajar di SDN 001 Pantai Raja Kecamatan Perhentian Raja Kabupaten Kampar. Tetapi pada penelitian saya, saya memfokuskan kepada upaya guru Fiqih mengembangkan media visual dalam proses pembelajaran di MAN Kuok 
Bangkinang Kabupaten Kampar. Jadi penelitian saya dan penelitian Lissuryani memiliki perbedaan baik dari judul penelitian, tempat penelitian, waktu penelitian, dan objek penelitian.

Konsep operasional adalah konsep yang digunakan untuk menjabarkan atau memberi batasan terhadap konsep teoritis. Hal ini bertujuan agar tidak terjadi kesalahan pengertian terhadap penelitian ini. Penelitian ini berkaitan dengan konsep upaya guru Fiqih mengembangkan media visual dalam proses pembelajaran di MAN Kuok Bangkinang Kabupaten Kampar.

Tabel 1:

Konsep Operasional

\begin{tabular}{ll}
\hline \multicolumn{1}{c}{ Variabel } & \multicolumn{1}{c}{ Indikator } \\
\hline Upaya guru mengembangkan media & 1. Menganalisis kebutuhan dan karakteristik \\
visual dalam proses pembelajaran bidang & siswa. \\
studi Fiqih di MAN Kuok Bangkinang & 2. Merumuskan tujuan \\
Kabupaten Kampar & 3. Merumuskan butir-butir materi secara \\
& terperinci yang mendukung tercapainya \\
& tujuan. \\
& 4. Mengembangkan alat pengukur keberhasilan. \\
& 5. Menulis naskah media. \\
& 6. Mengadakan tes dan revisi.
\end{tabular}

Media Visual adalah semua alat peraga yang digunakan dalam proses belajar yang bisa dinikmati lewat panca indera mata. Media Visual memegang peran yang sangat penting dalam proses belajar.

Secara garis besar kegiatan pengembangan media pembelajaran terdiri atas tiga langkah besar yang harus dilalui, yaitu kegiatan perencanaan, produksi dan penilaian. Sementara itu, dalam rangka melakukan desain atau rancangan pengembangan program media.

Arif Sadiman dan rekan-rekannya (Dalam Muhammad rohman; 122-128) memberikan urutan langkah-langkah yang harus diambil dalam pengembangan program media menjadi 6 (enam) langkah sebagai berikut:

\section{Pertama,} menganalisis kebutuhan dan karakteristik siswa. Kebutuhan dalam proses belajar mengajar adalah kesenjangan antara apa yang dimiliki siswa dengan apa yang diharapkan. Setelah kita menganalisis kebutuhan siswa, maka kita juga perlu menganalisis karakteristik siswanya, baik menyangkut kemampuan pengetahuan atau keterampilan yang dimiliki siswa sebelumnya. Cara mengetahuinya bisa dengan tes atau dengan yang lainnya. Langkah ini dapat disederhanakan dengan cara menganalisa topik-topik materi ajar yang dipandang sulit dan karenanya memerlukan bantuan media. Pada langkah ini sekaligus pula dapat ditentukan mana tujuan pembelajaran yang hendak dicapai, termasuk rangsangan indra mana yang diperlukan (audio, visual, gerak atau diam).

Kedua, merumuskan tujuan instruksional (instructional objetive) dengan operasional dan khas. Untuk dapat merumuskan tujuan instrusional dengan baik, yaitu: (a) Tujuan instruksional harus berorientasi kepada siswa. Artinya tujuan instruksional itu benar-benar harus menyatakan adanya prilaku siswa yang dapat dilakukan atau 
diperoleh setelah proses belajar dilakukan; dan (b) Tujuan harus dinyatakan dengan kata kerja yang operasioanal, artinya kata kerja itu menunjukkan suatu prilaku/perbuatan yang dapat diamati atau diukur.

Beberapa contoh dari kategori kata operasional adalah sebagai berikut:

Tabel 2:

Kategori Kata Operasional

\section{Kata kerja operasional}

Mengidentifikasikan.

Menyebutkan.

Menunjukkan.

Memilih.

Menjelaskan.

Menguraikan.

Merumuskan.

Menyimpulkan.

Mendemonstrasikan.

Membuat.

Menghitung.

Menunjukkan.

Menemukan.

Membedakan, dan lain-lain.

Sebuah tujuan pembelajaran hendaknya memiliki empat unsur pokok yang dapat kita akronimkan dalam ABCD (Audience, Behavior,
Kata kerja tidak operasioanal

Mengerti.

Memahami.

Menghargai.

Menyukai.

Mempercayai.

Dan lain-lain.

Tabel 3:

Akronim dalam ABCD

$\begin{array}{ll}\mathrm{A}= & \begin{array}{l}\text { Audience adalah menyebutkan sasaran/audiens yang dijadikan sasaran } \\ \text { pembelajaran. }\end{array} \\ \mathrm{B}= & \begin{array}{l}\text { Behavior adalah menyatakan prilaku spesifik yang diharapkan atau yang } \\ \text { dapat dilakukan setelah pembelajaran berlangsung. }\end{array} \\ \mathrm{C}= & \begin{array}{l}\text { Condition adalah menyebutkan kondisi yang bagaimana atau di mana sasaran } \\ \text { dapat mendemonstrasikan kemampuannya atau keterampilannya. }\end{array} \\ \mathrm{D}= & \begin{array}{l}\text { Degree adalah menyebutkan batasan tingkatan minimal yang diharapkan } \\ \text { dapat dicapai. }\end{array}\end{array}$

Ketiga, merumuskan butir-butir materi secara terperinci yang mendukung tercapainya tujuan. Penyusunan rumusan butir-butir materi adalah dilihat dari sub kemampuan atau keterampilan yang dijelaskan dalam tujuan khusus pembelajaran, sehingga materi yang disusun adalah dalam rangka mencapai tujuan yang
Condition,dan Degree). Penjelasan masing-masing komponen tersebut sebagai berikut : diharapkan dari kegiatan proses belajar mengajar terebut. Setelah daftar butirbutir materi dirinci maka langkah selanjutnya adalah mengurutkan dari yang sederhana sampai kepada tingkatan yang lebih rumit, dan dari hal yang konkret kepada yang abstrak.

Keempat, mengembangkan alat ukur keberhasilan. Alat pengukur 
keberhasilan seyogyanya dikembangkan terlebih dahulu sebelum naskah program ditulis. Dan alat pengukur ini harus dikembangkan sesuai dengan tujuan yang akan dicapai dan materimateri pembelajaran yang disajikan. Bentuk alat pengukurnya bisa dengan tes, pengamatan, penugasan atau cheklist prilaku.

Instrumen tersebut akan digunakan oleh pengembang media, ketika melakukan tes uji coba dari program media yang dikembangkannya. Misalnya alat pengukurnya tes, maka siswa nanti akan diminta mengerjakan materi tes tersebut. Kemudian dilihat bagaimana hasilnya. Apakah siswa menunjukkan penguasaan materi yang baik atau tidak dari efek media yang digunakan atau dari materi yang dipelajarinya melalui sajian media. Jika tidak maka dimanakah letak kekurangannya. Dengan demikian, maka siswa dimintai tanggapan tentang media tersebut, baik dari segi kemenarikan maupun efektifitas penyajiannya.

Kelima, menulis naskah media. Naskah media adalah bentuk penyajian materi pembelajaran melalui media rancangan yang merupakan penjabaran dari pokok-pokok materi yang telah disusun secara baik seperti yang telah dijelaskan di atas. Supaya materi pembelajaran itu dapat disampaikan melalui media, maka materi tersebut perlu dituangkan dalam tulisan atau gambar yang kita sebut naskah program media.

Naskah program media maksudnya adalah sebagai penuntun kita dalam memproduksi media. Artinya menjadi penuntun kita dalam mengambil gambar dan merekam suara. Karna naskah ini berisi urutan gambar dan grafis yang perlu diambil oleh kamera atau bunyi dan suara yang harus direkam.
Keenam, mengadakan tes atau uji coba dan revisi. Tes adalah kegiatan untuk menguji atau mengetahui tingkat efektifitas dan kesesuaian media yang dirancang dengan tujuan yang diharapkan dari program tersebut. Suatu program media yang oleh pembuatnya dianggap telah baik, tetapi bila program itu tidak menarik, sukar dipahami atau tidak merangsang proses belajar bagi siswa yang ditujunya, maka program semacam ini tentu saja tidak dikatakan baik.

Tes atau uji coba tersebut dapat dilakukan baik melalui perseorangan atau melalui kelompok kecil atau juga melalui tes lapangan, yaitu dalam proses pembelajaran yang sesungguhnya dengan menggunakan media yang dikembangkan. Sedangkan revisi adalah kegiatan untuk memperbaiki hal-hal yang dianggap perlu mendapatkan perbaikan atas hasil dari tes.

Jika semua langkah-langkah tersebut telah dilakukan dan telah dianggap tidak ada lagi yang perlu direvisi, maka langkah selanjutnya adalah media tersebut siap untuk ditampilkan.

Dengan demikian usaha guru Fiqih yang dimaksud dalam penelitian ini adalah untuk mengetahui apa saja upaya guru Fiqih mengembangkan media visual dalam proses pembelajaran di MAN Kuok Bangkinang Kabupaten Kampar.

\section{METODE}

Jenis penelitian yang digunakan dalam penelitian ini adalah penelitian deskriptif kualitatif. Penelitian ini bertujuan untuk mengetahui mengenai upaya guru Fiqih mengembangkan media visual dalam proses pembelajaran. 
Penelitian ini akan dilaksanakan di MAN Kuok, Jl. A. Rahman Samad Kuok Kecamatan Kuok Kabupaten Kampar. Penelitian ini akan dilakukan selama 4 bulan, terhitung mulai Januari-April 2016.

Subjek di dalam penelitian ini adalah guru bidang studi Fiqih di MAN Kuok. Sedangkan yang menjadi obyek dari penelitian ini adalah upaya guru mengembangkan media visual dalam proses pembelajaran bidang studi Fiqih di MAN Kuok Bangkinang Kabupaten Kampar.

Populasi dari penelitian ini adalah guru bidang studi Fiqih di MAN Kuok yang berjumlah 2 orang. Sedangkan sampel penelitian menggunakan tehnik total sampling, yaitu menjadikan semua populasi sebagai sampel dalam penelitian ini.

Adapun teknik yang penulis lakukan dalam pengumpulan data mengenai kemampuan guru bidang studi Fiqih dalam penyusunan dan pengembangan sumber belajar antara lain: (1) Teknik Wawancara. Teknik wawancara yaitu suatu teknik yang dilakukan dengan tanya jawab langsung kepada guru bidang studi Fiqih mengenai upaya guru mengembangkan media visual. Dalam hal ini penulis akan mewawancarai guru bidang studi Fiqih yang ada di sekolah tersebut, agar didapatkan data-data yang memang benar-benar sesuai dengan kenyataan yang ada; dam (2) Teknik Dokumentasi. Teknik dokumentasi yaitu suatu teknik yang digunakan untuk mengetahui sejarah sekolah, keadaan guru dan murid, kurikulum serta sarana dan prasarana.

Dalam teknik analisis data peneliti menggunakan teknik analisis deskriptif kualitatif. Oleh sebab itu dalam pengolahan data, peneliti menggunakan analisa data dengan menggunakan langkah-langkah yaitu: (1) Reduksi Data.Mereduksi data artinya merangkum, memilih hal-hal yang pokok, mefokuskan pada hal-hal yang penting, dicari tema dan polanya; (2) Penyajian Data. Setelah data reduksi, maka selanjutnya mendisplay data, yakni bisa dilakukan dalam bentuk uraian singkat, bagan, hubungan antar kategori, flowchart dan lain jenisnya; dan (3) Verifikasi. Verifikasi terakhir dalam analisis data kualitatif menurut Miles dan Hubermen adalah penarikan kesimpulan (Sugiono, 2012:247-252).

\section{HASIL \\ Gambaran Umum MAN Kuok Bangkinang}

Madrasah Aliyah Negeri Kuok adalah satu-satunya MAN yang ada di Kuok dan merupakan MAN tertua di Kabupaten Kampar. Madrasah Aliyah Negeri Kuok diresmikan sebagai Madrasah Aliyah Negeri pada tahun 1991. Ketika itu madrasah di pimpin oleh Bapak Drs. Nahdar Har. Awalnya MAN Kuok bernama MAN FILIAL Pekanbaru (cabang Pekanbaru) didirikan pada tahun 1972.

Seiring dengan berjalannya waktu dan tentunya dengan semangat kemajuan para pemimpin dan dukungan dari masyarakat, MAN Kuok dilokasikan pada tanah seluas 100 x 70 meter di jalan Ahmad Rahman Samad di Dusun Singolan raya tak jauh dari Pasar Kuok yaitu menempuh jarak lebih kurang $1 \mathrm{KM}$.

Madrasah Aliyah Negeri Kuok diputuskan menjadi MAN Negeri pada surat keputusan nomor 137 tahun 1991 tanggal 11 juli 1991. Diterbitkan oleh $\mathrm{H}$. Munawir Saizali. Sampai saat ini masih terbilang salah satu Madrasah berprestasi terbukti dengan prestasi dari berbagai perlombaan atau olimpiade yang diikuti oleh siswa MAN Kuok dan mendapat peringkat 1 dan 2. 
Adapun visi MAN Kuok Bangkinang Kabupaten Kampar adalah: "Visi Sekolah

Terwujudnya MAN Kuok sebagai Lembaga Pendidikan Islami, Terpadu, Mandiri dan Berkualitas serta Ramah Lingkungan". Sedangkan misi MAN Kuok Bangkinang Kabupaten Kampar adalah: “(1) Misi Sekolah; (2) Meningkatkan suasana kehidupan dilingkungan Madrasah menjadi masyarakat menjadi masyarakat yang Islami; (3) Menjadikan Bidang Studi umum sebagai kajian mendalami ilmu agama; (4) Meningkatkan mutu lulusan sesuai dengan tujuan pendidikan agama; (5) Menghasilkan lulusan yang berdaya guna bagi masyarakat; (6) Menjadikan MAN Kuok sebagai lembaga pendidikan yang dikenal dan diminati masyarakat; (7) Meningkatkan profesional guru dan karyawan dalam pemberdayaan potensi secara optimal; (8)Meningkatkan peran serta warga madrasah dalam rangka menciptakan lingkungan yang indah, rindang, dan bersih; (9) Memiliki muatan kurikulum yang berwawasan lingkungan; dan (10) Membudayakan hidup peduli terhadap lingkungan bagi seluruh warga madrasah".

\section{Penyajian Data}

Penyajian hasil data penelitian pada bab ini, merupakan hasil wawancara terhadap guru fiqih di MAN Kuok Bangkinang Kabupaten Kampar. Berikut ini penulis uraikan hasil wawancara yang penulis lakukan mengenai upaya guru dalam mengembangkan media visual dalam proses pembelajaran.

\section{Hasil Wawancara dengan ibu Nelfi Yanti, S.Hi}

T: Apakah ibu selalu
menganalisa $\quad$ kebutuhan

karakteristik siswa? Apa saja upaya ibu dalam menganalisa kebutuhan siswa? Apa saja upaya ibu dalam menganalisa karakteristik siswa?

$\mathrm{J}$ : Tentu, menganalisa kebutuhan dan karakteristik tersebut sangat penting. Upaya yang biasa ibu lakukan untuk menganalisa kebutuhan peserta didik diantaranya yaitu: (1) Melihat hasil belajar dari peserta didik sebelumnya; (2) Melihat materi yang diajarkan setiap semester; dan (3) Bagaimana prestasinya disekolah, jadi kita dapat membedakan tiap-tiap peserta didik sesuai dengan kebutuhannya. Upaya untuk menganalisa karakter peserta didik sangat mudah, jika kita guru yang mengajar peserta didik tersebut maka dengan seiringnya waktu kita akan mengetahui karakter mereka. Setiap hari ibu berjumpa dengan mereka disekolah, upaya yang ibu lakukan untuk menganalisa karakteristik siswa yaitu: (1) Memperhatikan tingkah lakunya; (2) Memperhatikan cara berbicara; dan (3) Cara mereka bergaul dengan teman mereka, guru, dll.

T: Apa saja upaya ibu dalam merumuskan tujuan instruksional? Kapan ibu merumuskan tujuan instruksional?

J: Upaya ibu lakukan untuk merumuskan tujuan instruksional yaitu: (1) Ibu melihat kurikulum; (2) Melihat materi pelajaran atau judul materi; (3) Memilih metode yang cocok untuk diajarkan. Ibu merumuskan tujuan instruksional itu biasanya sebelum proses belajar, atau awal tahun ajaran.

T: Apa saja upaya ibu dalam merumuskan butir-butir materi?

$\mathrm{J}$ : Butiran materi ini juga berkaitan dengan tujuan instruksioal tadi, upaya yang ibu lakukan untuk merumuskan butiran materi yaitu: (1) melihat kurikulum; (2) Memperhatikan materi; (3) Memperhatikan silabus; 
Menyusun dan mengurutkan butiran materi tersebut.

T: Apakah ibu pernah mengembangkan alat ukur keberhasilan belajar siswa? Apa saja upaya ibu mengembangkan alat ukur keberhasilan?

J: Pernah, upaya ibu untuk mengembangkan alat ukur keberhasilan dalam proses belajar mengajar yaitu: (1) Ibu membuat soal dan memberikan tugas kepada peserta didik; dan (2) Kemudian tinggal melihat hasilnya, agar bisa diperbaiki untuk kedepannya.

T: Apakah ibu pernah menulis naskah media? Apa upaya ibu untuk menulis naskah media yang baik dan benar?

J: Pernah, karna naskah media ini sangat membantu ibuk dalam proses belajar mengajar, menjadi pedoman agar urutan yang telah ibuk siapkan sebelum mengajar tidak terbolak balik. Upaya yang ibu lakukan untuk menulis naskah media yaitu: (1) Melihat judul materi; (2) Memilih media; dan (3) Menyediakan gambar.

T: Apakah ibu pernah
mengadakan tes dan revisi?
Bagaimana cara ibu untuk
mengadakan tes dan revisi agar
hasilnya baik? Apa upaya ibu untuk
mengadakan tes dan revisi?

$\mathrm{J}$ : Pernah, setelah proses belajar ibu mengadakan tes, setelah itu kesalahan-kesalahan diperbaiki, apakah cara penyampaian ibu sulit dipahami, menerangkan terlalu cepat, apakah media yang ibu sajikan tidak menarik, dll. Maka dari itu harus dilakukan revisi agar kesalahan yang sama tidak terulang lagi. Upaya yang ibu lakukan untuk mengadakan tes dan revisi yaitu: (1) Mencari media yang sesuai dengan materi; (2) Menulis naskah media; (3) Menyajikan dikelas; (4) Mencari kekurangan-kekurangan; dan Memperbaiki kekurangan tersebut.
Wawancara dengan bapak Syaifudin, S.Ag

T: Apakah bapak selalu menganalisa kebutuhan dan karakteristik siswa? Apa saja upaya bapak dalam menganalisa kebutuhan siswa? Apa saja upaya bapak dalam menganalisa karakteristik siswa?

J: Iya, upaya bapak untuk menganalisa kebutuhan siswa yaitu: (1) Tentunya kita harus mengenal dulu peserta didik; (2) Mengetahui kemampuan yang dimilikinya; (3) Serta tujuan akhir dari proses pembelajaran. Sedangkan untuk menganalisa karakteristik peserta didik juga sangat penting, karna jika kita tidak mengetahui karakteristik peserta didik yang kita ajar, maka akan sulit melaksanakan proses pembelajaran. Upaya bapak untuk menganalisa karakteristik siswa yaitu: (1) Mengenal dulu peserta didik itu, anak siapa, lingkungan tempat tinggalnya, dia tinggal dengan orang tua atau anak perantau; (2) Selebihnya bapak melihat tingkah lakunya didalam kelas, cara dia bergaul disekolah, baik dengan teman maupun guru.

T: Apa saja upaya bapak dalam merumuskan tujuan instruksional? Kapan bapak merumuskan tujuan instruksional?

J: Sebagai guru, bapak harus merumuskan tujuan instruksional sebelum proses pembelajaran. Upaya yang bapak lakukan untuk merumuskan tujuan instruksional yaitu:

Mempelajari kurikulum; (2) Memahami tujuan pengajaran agar menjadi jelas dan dapat dicapai oleh peserta didik. Dengan adanya tujuan instruksional kita mempunyai arah untuk memilih bahan pelajaran, memilih metode mengajar dan peserta didik mengetahui arah belajarnya. 
T: Apa saja upaya bapak dalam merumuskan butir-butir materi?

J: Upaya yang bapak lakukan untuk merumuskan butir-butir materi yaitu: (1) Untuk merumuskan butiran materi bapak melihat silabus; Melihat judul materi yang diajarkan; dan (3) Kemudian di pilah-pilah butiran materi tersebut.

\section{T: Apakah bapak pernah} mengembangkan alat ukur keberhasilan belajar siswa? Apa saja upaya bapak mengembangkan alat ukur keberhasilan?

J: Pernah, setiap semester bapak melakukan pengembangan alat ukur keberhasilan belajar siswa. Upaya yang bapak lakukan untuk mengembangkan alat ukur keberhasilan yaitu: (1) Melaksanakan pembelajaran; Mendorong dan memotivasi peserta didik; (3) Mengevaluasi pembelajaran; (4) Mengadakan latihan, ulangan, ujian, dan memberikan tugas. Kemudia kita akan mengetahui apakah peserta didik menguasai meteri dengan berbagai media yang telah disediakan.

T: Apakah bapak pernah menulis naskah media? Apa upaya bapak untuk menulis naskah media yang baik dan benar?

J: Pernah, upaya yang bapak lakukan untuk menulis naskah media yaitu: (1) Kadang-kadang bapak cuma melihat dari semester sebelumnya; (2) Menyesuaikan dengan materi; (3) Menambahkan apa yang perlu ditambahkan; (4) Menghapus yang dirasa tidak penting. Karna dengan menulis naskah media mempermudah bapak mengajar dikelas, semua berjalan sesuai dengan media dan metode yang telah bapak siapkan.

T: Apakah bapak pernah
mengadakan tes dan revisi?
Bagaimana cara bapak untuk
mengadakan tes dan revisi agar
hasilnya baik? Apa upaya bapak
untuk mengadakan tes dan revisi?

J: Pernah, apabila media itu belum pernah ditampilkan dikelas, maka kita terlebih dahulu melakukan tes dibeberapa kelas. Setelah itu direvisi, dimana letak kekurangan dari media tersebut. Upaya yang bapak lakukan yaitu: (1) Mengenalkan media-media baru; (2) Mencoba media tersebut dikelas; (3) Melihat minat belajar peserta didik dan melihat hasil belajarnya; (4) Mencari kekurangan dari media; (5) Melakukan revisi.

\section{Analisis Data}

Setelah melakukan penelitian dan pengambilan data, maka data yang telah ada dianalisis untuk mengetahui hasil dari upaya guru mengembangkan media visual, apa saja upaya yang dilakukan dalam mengembangkan media visual dalam proses pembelajaran bidang studi Fiqih.

\section{Menganalisis Kebutuhan dan Karakteristik Siswa \\ Adapun upaya guru dalam} menganalisa kebutuhan siswa yaitu pertama tentunya kita harus mengenal dulu peserta didik. Guru pasti mengenal peserta didiknya dan begitu juga sebaliknya, dengan mengenal maka guru akan mengetahui apa saja yang dibutuhkan oleh peserta didiknya. Kedua melihat hasil belajar dari peserta didik. Dengan kita melihat hasil belajar dari peserta didik, maka guru akan mengetahui materi mana yang dipahami dan yang sulit dipahami peserta didik. Selanjutnya guru akan lebih mengajarkan materi yang tidak dipahami peserta didik secara mendalam. Ketiga melihat prestasi peserta didik disekolah. Prestasi bisa menggambarkan keberhasilan guru dalam mengajar, semakin banyak peserta didik yang berprestasi maka 
semakin besar keberhasilan guru dalam mengajar.

Adapun upaya guru dalam menganalisa karakteristik siswa yaitu pertama Mengenal dulu peserta didik itu, anak siapa, lingkungan tempat tinggalnya, dia tinggal dengan orang tua atau anak perantau. Untuk mengetahui karakter peserta didik itu seorang guru harus mengenal dulu peserta didiknya. Kedua Selebihnya bapak melihat tingkah lakunya didalam kelas, cara dia bergaul disekolah, baik dengan teman maupun guru. Karakter peserta didik akan tergambar dari kesehariannya disekolah, seorang guru harus bisa menilai hal tersebut agar guru bisa membedakan mana peserta didik yang mempunyai karakter yang baik dan mana peserta didik yang mempunyai karakter yang kurang baik.

\section{Merumuskan Tujuan Instruksional}

Adapun upaya guru dalam merumuskan tujuan instruksional yaitu pertama Mempelajari kurikulum. Kurikulum telah disediakan departemen agama, jadi guru hanya melihat, memahami dan mempelajari kurikulum tersebut. Kedua Memahami tujuan pengajaran agar menjadi jelas dan dapat dicapai oleh peserta didik. Dengan adanya tujuan instruksional kita mempunyai arah untuk memilih bahan pelajaran, memilih metode mengajar dan peserta didik mengetahui arah belajarnya

\section{Merumuskan Butir-butir Materi}

Adapun upaya guru dalam merumuskan butir-butir materi yaitu pertama Melihat kurikulum. Kurikulum telah disediakan, jadi guru hanya melihat, memahami dan mempelajari kurikulum tersebut. Kedua Melihat judul materi yang diajarkan. Sebelum guru mengajar tentunya guru telah mengetahui dan mempelajari meteri yang akan disampaikan dikelas, agar proses belajar mengajar berjalan lancar. Ketiga Menyusun dan mengurutkan materi. Materi harus di pilah-pilah serta di urutkan, agar butiran materi tersebut menjadi terarur dan bisa dirumuskan butiran-butiran materi.

\section{Mengembangkan Alat Pengukur Keberhasilan}

Adapun upaya guru dalam mengembangkan alat pengukur keberhasilan yaitu pertama Melaksanakan pembelajaran. Setelah belajar barulah guru bisa mengetahui keberhasilan dalam belajar mengajar. Kedua Membuat soal dan memberikan tugas kepada peserta didik. Soal adalah salah satu alat yang bisa mengukur keberhasilan dalam belajar, apabila nilai yang diperoleh peserta didik tinggi, maka alat pengukur keberhasilan tersebut bisa dikatakan sukses. Begitu juga sebaliknya apabila nilai yang diperoleh peserta didik rendah, maka alat pengukur keberhasilan tersebut bisa dikatakan gagal. Ketiga Mengevaluasi pembelajaran. Evaluasi adalah proses penilaian yang dilakukan oleh guru, proses evaluasi bisa dilakukan setelah mengajar, setiap hari, setiap minggu, setiap bulan, setiap semester, dan lain-lain.

\section{Menulis Naskah Media}

Adapun upaya guru dalam menulis naskah media yaitu pertama Melihat judul materi. Untuk membuat naskah media guru harus menyesuaikan dengan judul materi yang akan disampaikan di kelas. Kedua Memilih media. Didalam naskah media harus ditentukan media apa yang mau digunakan, gambar yang mau ditampilkan, serta langkah-langkah mengunakan media tersebut. Ketiga 
Menyediakan gambar. Setelah itu guru menyediakan gambar-gambar yang telah dipilih dan media siap disajikan kepada peserta didik.

\section{Mengadakan Tes dan Revisi}

Adapun upaya guru dalam mengadakan tes dan revisi yaitu pertama Mencari media yang sesuai dengan materi. Suatu media harus dilakukan tes untuk menguji tingkat kesesuaian media yang dirancang dengan tujuan yang diharapkan dari pembelajaran. Kedua Mencoba media tersebut dikelas. Media digunakan dalam belajar dan harus dicoba dulu untuk mengetahui daya tarik dari media dan ketertarikan peserta didik terhadap media yang telah dirancang. Ketiga Mencari kekurangan dari media. Setelah mencoba media dikelas maka akan ditemukan kekurangan-kekurangan dari media tersebut maka langkah selanjutnya direvisi. Keempat Melakukan revisi. Revisi adalah kegiatan untuk memperbaiki hal-hal yang dianggap perlu mendapatkan perbaikan dari tes yang telah dilakukan.

\section{SIMPULAN}

Berdasarkan hasil penelitian dan analisis data, maka dapat disimpulkan bahwa upaya guru mengembangkan media visual dalam proses pembelajaran bidang studi Fiqih di MAN Kuok dapat dikatakan baik, adapun upaya yang dilakukan adalah: Pertama guru melakukan upaya menganalisis kebutuhan dan karakteristik siswa dengan, upaya untuk menganalisis kebutuhan siswa dengan; Mengenal peserta didik; Melihat prestasi peserta didik disekolah. Upaya guru untuk menganalisis karakteristik siswa dengan; Mengenal dulu peserta didik itu, anak siapa, lingkungan tempat tinggalnya, dia tinggal dengan orang tua atau anak perantau; Melihat tingkah lakunya didalam kelas, cara dia bergaul disekolah, baik dengan teman maupun guru. Kedua guru melakukan upaya merumuskan tujuan instruksional dengan; Memahami tujuan pengajaran agar menjadi jelas dan dapat dicapai oleh peserta didik. Ketiga guru melakukan upaya merumuskan butirbutir materi dengan; Melihat kurikulum; Melihat judul materi yang diajarkan; Menyusun dan mengurutkan materi. Keempat guru melakukan upaya mengembangkan alat pengukur keberhasilan dengan; Melaksanakan pembelajaran; Membuat soal dan memberikan tugas kepada peserta didik; Mengevaluasi pembelajaran. kelima guru melakukan upaya menulis naskah media dengan; Melihat judul materi; Memilih media; Menyediakan gambar. Keenam guru melakukan upaya mengadakan tes dan revisi dengan; Mencari media yang sesuai dengan materi; Mencoba media tersebut dikelas; Mencari kekurangan dari media; Melakukan revisi.

\section{DAFTAR RUJUKAN}

Abdussalam, Suroso. 2011. Arah dan Azas Pendidikan Islam. Jakarta: Sukses Publishing.

Anwar, Dessy. 2011. Kamus Lengkap Bahasa Indonesia. Surabaya: Karya Aditma.

Arsyad, Azhar. 2011. Media Pembelajaran. Jakarta: Rajawali Pers.

Dairi, Rizal. 2010. Metodologi Penelitian. Pekanbaru: UIR Press.

Depatemen Pendidikan Nasional. 2005. Kamus Besar Bahasa Indonesia. Jakarta: Balai Pustaka.

Djamarah, Syaiful Bahri. 2011. Psikologi Belajar. Jakarta: Rineka Cipta. 
Febliza, Asyti dan Afdal, Zul. 2015. Media Pembelajaran dan Teknologi Informasi Komunikasi. Jakarta: Adefa Grafika.

K., Koyo, dkk., 2013. Media Pendidikan. Jakarta: Dirjen Dikti.

Keputusan Presiden Undang-undang Dasar Republik Indonesia nomor 14 tahun 2005 dan Peraturan Mentri Pendidikan Nasional RI Nomor 11 tahun 2011 tentang Guru dan Dosen.

Latipah, Eva. 2012. Pengantar Psikologi Pendidikan. Yogyakarta: PT Pustaka Insani Madani.

Lissuryani. 2012. Kemampuan Guru Pendidikan Agama Islam dalam Penyusunan dan Pengembangan Bahan Ajar di SDN 001 Pantai Raja Kecamatan Perhentian Raja Kabupaten Kampar. Skripsi. Pekanbaru: Perpustakaan FAI UIR.

Pidarta, Made. 2007. Landasan Kependidikan. Jakarta: PT Rineka Cipta.

Porter, Bobbi De. 2003. Membiasakan Belajar Nyaman dan Menyenangkan. Bandung: Kaifa.

Rahman, Muhammad dan Amri, Sofan. 2013. Strategi dan Desain Pengembangan Sistem Pembelajaran. Jakarta: Prestasi Pustakaraya.

Ramayulis. 2013. Profesi dan Etika Keguruan. Jakarta: Kalam Mulia.

Rozita, Eni. 2012. Usaha Guru Menggunakan Media dalam Proses
Belajar Mengajar di PDTA Al-Huda Kecamatan Kundur Kabupaten Karimun. Skripsi. Pekanbaru: Perpustakaan FAI UIR.

Sadiman, Arif S., dkk., 2006. Media Pendidikan. Jakarta: Rajawali Pers.

Saleh, Abdul Rachman. 2006. Pendidikan Agama dan Membangun Watak Bangsa. Jakarta: Raja Grafindo.

Slameto. 2013. Belajar dan FaktorFaktor yang Mempengaruhinya. Jakarta: Rineka Cipta.

Sudijono, Anas. 2003. Pengantar Evaluasi Pendidikan. Jakarta: Raja Grafindo Persada.

Sugiono. 2012. Metode Penelitian Berbasis Bisnis. Bandung: Alfabeta.

Uhbiyati, Nur. 2005. Ilmu Pendidikan Islam. Bandung: Pustaka Setia.

Undang-undang Dasar Republik Indonesia Nomor 14 Tahun 2005 dan peraturan Mentri Pendidikan Nasional RI Nomor 11 Tahun 2011 Tentang Guru dan Dosen.

Utari, Endang. 2015. Upaya Guru dalam Memanfaatkan Sumber Pembelajaran Bidang Studi Pendidikan Agama Islam di Sekolah Menengah atas Negeri 5 Dumai. Skripsi. Pekanbaru: Perpustakaan FAI UIR.

Wiyani, Novan Ardy. 2012. Ilmu Pendidikan Islam. Yogjakarta: Arruzz Media. 